\title{
Characterization of Potential Driver Genes Involved in Human Breast Cancer in Maysan Province, Iraq
}

Zainab Zamil gataa Allami

University of Misan

Maytham A Dragh ( $\square$ maithamdragh@uomisan.edu.iq)

University of Misan

\section{Research Article}

Keywords: polymorphism, Iraqi, breast cancer, drug resistance gene, tumor suppressor gene, estrogen receptor a gene, regulatory gene.

Posted Date: November 12th, 2021

DOI: https://doi.org/10.21203/rs.3.rs-963055/v1

License: (a) This work is licensed under a Creative Commons Attribution 4.0 International License. Read Full License 


\section{Abstract}

Background: Breast cancer is a heterogeneous disease regarding its morphology, invasive behaviour, metastatic capacity, hormone receptor expression and clinical outcome. There are many risk factors for breast cancer, including genetic factors that account for $25-30 \%$ of the incidence; from this percentage, only $15-30 \%$ of the heritable component of breast cancer is due to known familiar highly penetrating genes, and the others are sporadic.

Methods: This study was the first to include amplified genes as PCR templates to determine the relationship between their polymorphism and breast cancer incidence using RAPD of amplified genes. The study was designed first to evaluate the association of ABCG2, ABCB1 and BRCA1 gene polymorphisms in addition to miRNA-152 and ER-a using the RAPD technique with breast cancer incidence in Maysan Province women and second to use those genes as indicators for breast cancer prediction and diagnosis. The study included 100 patients with breast cancer and 30 healthy control women, and then all samples were amplified by conventional PCR with specific $F$ and $R$ primers for ABCG2, ABCB1, BRCA1, ER-a, and miRNA-152 genes. Then, the best PCR product (20) was chosen as the template for the RAPD technique.

Results: The results revealed that all RAPD primers showed polymorphisms with higher values and more specific bands in patient samples. Our study proved the relationship between genetic polymorphisms of breast cancer-related genes and a higher incidence of cancer.

Conclusion: The current study recommends employing these results for the future prediction and diagnosis of breast cancers.

\section{Introduction:}

Breast cancer (BC) is the most common cancer in women around the world, accounts for $15 \%$ of cancer deaths among women, and is the leading cause of cancer death in females worldwide (Jin.,2020). In Iraq, breast cancer is the most common pattern of female malignancy, accounting for approximately one-third of the registered female cancers according to the Iraqi cancer registry in 2004 (Mohammed, 2011; Ismaeel, 2013; Mohammed, 2018). 5-10\% of breast cancer are inherited (ALHannan al.,2019); while 90-95\% are sporadic;are cases that show randomly and are not predetermined genetically (Antoniou et al.,2003;sabra.,2020).

Susceptible genes are critical risk factors for both hereditary and sporadic breast cancers. However, the genesis of breast cancer usually involves accumulative mutations of various genes (Xie.,2020). several genes are found related to breast cancer (Sun et al.,2017);such as ABCG2 gene that is located on human chromosome at the locus 4q 22.1 (Ni et al.,2010;Haider et al.,2011; Chen et al.,2019),ABCB1 gene also named (MDR1 gene) is located on chromosome 7q21.12 (Sheng $X$ et al.,2012; içDUYGU et al.,2020);ABCB1,ABCG2 belongs to a large ATPbinding cassette $(A B C)$ transporters; including Pglycoprotein (P-gp);Overexpression of specific genes, mutation of drug targets, overexpression of $A B C$ transporters, increased anti-apoptotic machinery and DNA damage repair machinery, and enhanced drug inactivation mechanism are concerned in the intrinsic or acquired resistance to chemotherapy (Manandhar et al., 2017; Nayak et al.,2020); BRCA1 (tumour suppressor gene) is situated on chromosome 17q21 (Rebbeck et al.,2016; Ndiaye et al.,2020); is the major cause of familial breast cancer(ALHannan et al.,2019); BRCA1 protein that has been associated in several celluar processes, including genomic stability, the cell cycle checkpoint, DNAdamage repair, apoptosis and gene transcription (Meshram.,2019). ER-a gene is located on chromosome 6q25.1; ERa receptor super family have main function in development and progression of cancer, it also stimulates mammary epithelial tissue proliferation and differentiation through combining with estrogen (Ponglikitmongkol et al.,1988.,Abd Ellatif et al.,2016;AL-Amri et al.,2020); However, the allele variant has been shown to be associated with BC risk in different populations(chauhan et al.,2019).miRNA -152 gene is situated on chromosome 17q21.32 (Zhou et al.,2012;Liu et al.,2016) that main function in the regulation of biological processes such as differentiation, proliferation and apoptosis (Md and lund.,2012;Ge et al.,2017).

RAPD can be defined as a DNA fingerprinting technique based on polymerase chain reaction amplification of random fragments of genomic DNA with single short primers of arbitrary nucleotide sequences (Kumar and Gurusubramanian, 2011; Sharma and Singh, 2017). RAPD is a semiquantitative method more commonly used to detect polymorphisms in genetic mapping, taxonomy and phylogenetic studies and later in genotoxicity and carcinogenesis studies (Atienzar and Jha, 2006). RAPD analysis was used in studies in the field of genetic instability in breast cancer (Novikov et al., 2016).

In this study, we performed a new procedure with some modifications to the traditional RAPD technique when we used the amplified gene as a template in RAPD. This procedure resulted in more accuracy and yielded more specific data. We named it PCR-RAPD-PCR (PRP). The aim of this study was to evaluate the genetic polymorphism of the BC gene in women with breast cancer in Maysan Province, southern Iraq.

\section{Materials And Methods:}

\subsection{Study sites}


All methods were carried out in accordance with relevant guidelines and regulations. The experimental protocols were approved by ethics committee/IRB [scientific committee of Biology Department/college of science/Misan university]. The study was undertaken in the genetic engineering laboratory/biology department/college of science/Misan University. A total of 100 blood samples were collected from women with breast cancer and 30 healthy women in the Maysan Health Directorate/AL-Sader Teaching Hospital/AL-Shifa Tumor Treatment Center in/ALAmarah city (subdistricts of Maysan Province, southern Iraq).

\subsection{Samples collection and identification}

Informed consent was obtained from all participants.. Approximately 100 blood samples (2-3 mL) were collected from each woman with breast cancer (in case the woman was healthy) or blood samples $(1 \mathrm{~mL}$ ) were collected from each women with breast cancer (in case the woman was healthy). Blood samples were collected from each woman patient through the median cubital vein or through palm veins (according to health condition) into EDTA-containing tubes and were stored at $-20^{\circ} \mathrm{C}$ until DNA extraction.

\subsection{Genomic DNA isolation}

All samples were collected from women with breast cancer at different times for three months (September to November). All samples were kept under the same conditions. DNA was extracted from whole blood by using the ${ }_{g}$ SYNC $^{T M}$ DNA Extraction Kit Functional Test Data (Geneaid, Taiwan).

\subsection{Column purification}

Genomic DNA was isolated from the all blood. The amount of isolated DNA varied from 523.92 to $887.12 \mathrm{ng} / \mathrm{ml}$ DNA, and an absorbance ratio of A260/280 was obtained in the range of 1.71-1.98 according to Surzycki (2012).

\subsection{Polymerase chain reaction for isolated PCR products (specific BC genes)}

DNA was isolated from all 100 women with BC and 30 normal women; genomic DNA samples were prepared by pooling the same amount of genomic DNA from each individual. The DNA fragments of PCR product of BC genes were amplified through polymerase chain reaction technique.The following components: $2.5 \mu \mathrm{l}$ primer F, $2.5 \mu \mathrm{l}$ primer R,2.5 $\mu$ l Nuclease free water, $12.5 \mu \mathrm{l} \mathrm{GO} \mathrm{Taq}{ }^{\circledR} G 2$ Green master mix and $5 \mu \mathrm{l}$ DNA template were added for each 25 reaction mixture. The primer sequences were (Table 1)

Table (1) Sequence of primers, GC\% and length are shown

\begin{tabular}{|llllll|}
\hline primer & Sequence & GC\% & Length (Base) & References \\
\hline ABCG2 & $\begin{array}{l}\text { 5-AAAT GTTCATAG CCAGTTTCTTGGA-3 } \\
\text { 3-ACAGTAATGTCGAAGTTTTTA TCGCA-5 }\end{array}$ & $35.29 \%$ & F:25 & R:26 & Wu et al.,2015 \\
\hline ABCB1 & $\begin{array}{l}\text { 5-TTGATGGCAAAG AAATAAAGC-3 } \\
\text { 3-CTTACATTAGGCAGTGAC TCG-5 }\end{array}$ & $40.47 \%$ & F:21 & R:21 & Tazzite et al., 2016 \\
\hline BRCA1 & 5-CAC CTC CAA GGT GTA TGA AG-3 & $50 \%$ & F:20 & R:22 & Gholipoorfeshkechen and \\
& 3-CTC TAG GAT TCT CTG AGC ATG G-5 & & & Arjunan.,2014 \\
\hline miRNA-152 & 5-TCTGTCATGCACTGACTGCTC-3 3GGGCATGCTTCTGGAGTCTA-5 & $53.65 \%$ & F:21 & R:20 & Nguyen-Dien et al.,2014 \\
\hline ER-a & 5-ATG CGC TGC GTC GCC TCTAA-3 & $60 \%$ & F:20 & R:20 & Sato et al.,2008 \\
\hline
\end{tabular}

The PCR consisted of 35 cycles following three essential steps: initial denaturation ( 5 min at $\left.94^{\circ} \mathrm{C}\right)$, DNA denaturation $\left(1 \mathrm{~min}\right.$ at $\left.94^{\circ} \mathrm{C}\right)$, primer annealing ABCG2 (45 sec at gradient 53.5-58.5 $\left.5^{\circ} \mathrm{C}\right)$; primer annealing ABCB1 $\left(1 \mathrm{~min}\right.$ at $\left.53^{\circ} \mathrm{C}\right)$, primer annealing BRCA1 $\left(35 \mathrm{sec}\right.$ at $\left.55^{\circ} \mathrm{C}\right)$, primer annealing ER-a (45 sec at gradient $\left.52-58^{\circ} \mathrm{C}\right)$, primer annealing miRNA-152 $\left(15 \mathrm{sec}\right.$ at $\left.65^{\circ} \mathrm{C}\right)$, and primer extension $\left(1 \mathrm{~min}\right.$ at $\left.72^{\circ} \mathrm{C}\right)$. There was a final extension cycle for $7 \mathrm{~min}$ at $72^{\circ} \mathrm{C}$. The size of the amplified PCR product was subjected to electrophoresis in a $1.2 \%$ agarose gel and $1 \mathrm{X}$ TBE buffer with ethidium bromide $2 \%$ at $80 \mathrm{~V}$ for $60 \mathrm{~min}$. The bands were visualized under ultraviolet trans-illumination and photographed in Gel-Doc equipment. The PCR product with a clear band was later used as a template in the RAPD-PCR technique.

\subsubsection{Purify PCR Product by gel extraction:}

PCR products were obtained after a conventional PCR run; PCR products were extracted from agarose gel after gel electrophoresis for BCrelated genes by using the E.Z.N.A.® Gel Extraction kit Spin protocol (OMEGA BIO-TEK, USA).

\subsubsection{Column Purification}


The PCR product (specific gene) was isolated from the DNA gel extraction, the amount of isolated DNA PCR product (specific gene) varied from $523.92-887.12 \mathrm{ng} / \mathrm{ml}$, and an absorbance ratio of A260/280 was obtained in the range of 1.71-1.98.

\subsubsection{PCR RAPD PCR}

Isolated PCR product from all women BC Patient and normal DNA;the same best 40 PCR product (20 patient and 20 control) of ABCG2,ABCB1,BRCA1,ER-a,miRNA-152 genes were chosen for PCR- RAPD- PCR The primer sequences (Table 2).

Table (2) Sequence of RAPD primers, GC\% and length are shown

\begin{tabular}{|llll|}
\hline Primers & Primers Sequences & GC\% & Length (Base) \\
\hline OPAA11 & 5-ACCCGACCTG-3 & $\% 80$ & 10 Base \\
\hline OPU15 & 5-ACGGGCCAGT -3 & $70 \%$ & 10 Base \\
\hline OPAA17 & 5-GAGCCCGACT -3 & $70 \%$ & 10 Base \\
\hline OPD18 & 5-GAGAGCCAAC- 3 & $60 \%$ & 10 Base \\
\hline
\end{tabular}

The reaction mixture $(20 \mu \mathrm{L})$ consisted of template PCR product $2.5 \mu \mathrm{l}, 2.5 \mu \mathrm{L}$ (OPAA11, OPU15, OPAA17, OPD18) RAPD primer, $7.5 \mu \mathrm{l}$ nucleasefree water, and $7.5 \mu \mathrm{l} \mathrm{GO} \mathrm{Taq}{ }^{\circledR} \mathrm{G} 2$ Green master mix. The mixture was incubated in the TECHNE prime thermal cycler (with heating lid) programmed for 35-40 cycles, each consisting of the following: a denaturation step ( 1 min at $\left.94^{\circ} \mathrm{C}\right)$, one annealing step (30 sec at gradient 36 $39^{\circ} \mathrm{C}$ ) and an extension step $\left(1 \mathrm{~min}\right.$ at $\left.72^{\circ} \mathrm{C}\right)$. After cycling, a final extension for $1.30 \mathrm{~min}$ at $72^{\circ} \mathrm{C}$ was followed by slow cooling to $10^{\circ} \mathrm{C}$. Four RAPD primers (OPAA11, OPU15, OPAA17, OPD18) were used in the amplifications. The primers were obtained from AUGCT DNA SYN Biotechnology (China).

\subsubsection{Electrophoretic analysis}

The reaction products were separated by electrophoresis on an agarose gel (1.2\%) containing ethidium bromide (2\%) and prepared in $1 \mathrm{X}$ TBE buffer. The DNA ladder size marker used in this study contained many discrete bands (in base pair): 1500, 1000, 900, 800, 700, 600, 500, 400, $300,200,100,75,50$ and 25 bp from the nearest distance to the well to the far from the well, respectively. This ladder was used as a molecular size indicator in the experiments of this study. The DNA fragments obtained were visualized under ultraviolet light, and the molecular sizes of the DNA bands were estimated according to a standard curve representing the relationship between the band molecular size of the ladder measured by base pairs and the distance of migration bands (Sambrook \& Russell, 2001).

\subsection{Statistical analysis}

The RAPD-PCR product from all experiments was scored, the molecular weight of all bands was calculated, and a binary matrix was prepared by scoring as absence and presence. Each RAPD-PCR product was assumed to represent a single locus. To consider a marker polymorphic, the absence or addition of an amplified product in at least one sample was used as a criterion (Seufi et al., 2009). The bioinformatics toolkit in MATLAB was used for cluster statistical analysis to group the RAPD-PCR bands into respective categories to create a phylogenetic tree to investigate the relationships (genetic distance) among the genomic DNA of BC patients.

\section{Results:}

We identified five genes related to breast cancer BC (ABCG2, ABCB1, BRCA1) associated with drug resistance and (ER-a and miRNA-152 genes) associated with receptor and estrogen responses. We performed conventional PCR assays and yielded single bands at approximately 300 bp, $200 \mathrm{bp}, 500 \mathrm{bp}, 500 \mathrm{bp}$, and $180 \mathrm{bp}$. The genetic polymorphism of the included genes was determined by four RAPD primers (OPAA11, OPU15, OPAA17, OPD 18). Amplified BC genes were used as templates in the PCR-RAPD-PCR technique (PRP). The PRP results showed that RAPD primers were able to generate polymorphic, monomorphic, unique bands with different ratios between BC patients and controls (Figures 1 , 2, 3).

Our findings showed a difference in the primer discriminatory power among BC-related genes in the patient and control, whereas the high discriminatory power in the patient was $40 \%$ at OPU15, the highest primer discriminatory power in the control was 42.85 at OPAA11, the highest primer efficiency in the patient was 0.037 at OPD18, and the highest primer efficiency in the control was 0.078 at OPU15 (figure 4 ).

the overall number of bands in the patients were $(214,215,206,298,149)$ band for ABCG2,ABCB1,BRCA1,ER-a, mi-RNA 152 genes, respectively with total number of bands (1082) while the total bands of the control were $(162,114,126,128,93)$; with total number of (623) band figure (5). 
The total polymorphic bands in all genes were 85 band in patient, while in control were 69 band; The overall monomorphic bands in all genes in patients were 52 bands, while in control were 40 bands; The overall total unique bands in all genes together were 36 band in patient, while in control were 24 band. (Table 3,4 )

Table 3

Polymorphism, primer efficiency, primer discrimination, uniquely and monomorphism of drug resistance genes

\begin{tabular}{|c|c|c|c|c|c|c|c|c|c|}
\hline Gene & $\begin{array}{l}\text { RAPD } \\
\text { Primer }\end{array}$ & $\begin{array}{l}\text { Total } \\
\text { No. of } \\
\text { bands }\end{array}$ & $\begin{array}{l}\text { Total No. of } \\
\text { polymorphic } \\
\text { bands }\end{array}$ & $\begin{array}{l}\text { Polymorphism } \\
\%\end{array}$ & $\begin{array}{l}\text { Primer } \\
\text { efficiency }\end{array}$ & $\begin{array}{l}\text { Primer } \\
\text { discriminatory } \\
\text { power \% }\end{array}$ & $\begin{array}{l}\text { Total } \\
\text { No. of } \\
\text { unique } \\
\text { bands }\end{array}$ & $\begin{array}{l}\text { Uniqueness, } \\
\%\end{array}$ & $\begin{array}{l}\text { Total No. of } \\
\text { Monomorphic } \\
\text { bands }\end{array}$ \\
\hline \multirow{4}{*}{$\begin{array}{l}\text { ABCG2 } \\
\text { patient }\end{array}$} & OPAA11 & 58 & 4 & 6.8965 & 0.018 & 26.66 & 1 & 1.724 & 3 \\
\hline & OPU 15 & 56 & 6 & 10.714 & 0.028 & 40 & 0 & 0 & 3 \\
\hline & OPAA17 & 46 & 3 & 6.5217 & 0.014 & 20 & 5 & 10.86 & 3 \\
\hline & OPD 18 & 54 & 2 & 3.7037 & 0.009 & 13.33 & 4 & 7.407 & 3 \\
\hline Total & & 214 & 15 & 7.1770 & & & 10 & 4.784 & 12 \\
\hline ABCG2 & OPAA11 & 45 & 6 & 13.333 & 0.037 & 42.85 & 2 & 4.4444 & 4 \\
\hline \multirow[t]{3}{*}{ Control } & OPU15 & 39 & 4 & 10.256 & 0.024 & 28.57 & 2 & 5.1282 & 4 \\
\hline & OPAA17 & 40 & 2 & 5 & 0.012 & 14.28 & 0 & 0 & 4 \\
\hline & OPD18 & 38 & 2 & 5.2631 & 0.012 & 14.28 & 2 & 5.2631 & 4 \\
\hline Total & & 162 & 14 & 8.6419 & & & 6 & 3.7037 & 16 \\
\hline \multirow{4}{*}{$\begin{array}{l}\text { ABCB1 } \\
\text { patient }\end{array}$} & OPAA11 & 57 & 6 & 10.5263 & 0.027 & 24 & 2 & 3.5087 & 1 \\
\hline & OPU 15 & 51 & 5 & 9.80392 & 0.023 & 20 & 1 & 1.9607 & 1 \\
\hline & OPAA17 & 54 & 6 & 11.111 & 0.027 & 24 & 2 & 3.7037 & 1 \\
\hline & OPD 18 & 53 & 8 & 15.0943 & 0.037 & 32 & 3 & 5.6603 & 1 \\
\hline Total & & 215 & 25 & 11.6279 & & & 8 & 3.7209 & 4 \\
\hline ABCB1 & OPAA11 & 32 & 4 & 12.5 & 0.035 & 30.76 & 0 & 0 & 1 \\
\hline \multirow[t]{3}{*}{ Control } & OPU15 & 22 & 4 & 18.1818 & 0.035 & 30.76 & 1 & 4.5454 & 1 \\
\hline & OPAA17 & 26 & 1 & 3.84615 & 0.008 & 7.69 & 2 & 7.6923 & 1 \\
\hline & OPD18 & 34 & 4 & 11.7647 & 0.035 & 30.76 & 0 & 0 & 1 \\
\hline Total & & 114 & 13 & 11.4035 & & & 3 & 2.6315 & 4 \\
\hline BRCA1 & OPAA11 & 51 & 3 & 5.8823 & 0.014 & 15.78 & 3 & 5.88235 & 3 \\
\hline \multirow[t]{3}{*}{ Patient } & OPU 15 & 68 & 5 & 7.3529 & 0.024 & 26.31 & 3 & 4.41176 & 3 \\
\hline & OPAA17 & 45 & 5 & 11.11 & 0.024 & 26.31 & 2 & 4.4444 & 3 \\
\hline & OPD 18 & 42 & 6 & 14.285 & 0.029 & 31.57 & 3 & 7.14285 & 3 \\
\hline Total & & 206 & 19 & 9.2233 & & & 11 & 5.3398 & 12 \\
\hline \multirow{4}{*}{$\begin{array}{l}\text { BRCA1 } \\
\text { control }\end{array}$} & OPAA11 & 42 & 3 & 7.14285 & 0.023 & 37.5 & 1 & 2.38095 & 3 \\
\hline & OPU 15 & 30 & 2 & 6.66666 & 0.015 & 25 & 2 & 6.66666 & 3 \\
\hline & OPAA17 & 29 & 3 & 10.3448 & 0.023 & 37.5 & 1 & 3.44827 & 3 \\
\hline & OPD 18 & 25 & 0 & 0 & 0 & 0 & 4 & 16 & 3 \\
\hline Total & & 126 & 8 & 6.34920 & & & 8 & 6.34920 & 12 \\
\hline
\end{tabular}


Table 4

Polymorphic monomorphic, unique band, primer efficiency, primer discriminatory power of receptor and estrogen response gene.

\begin{tabular}{|c|c|c|c|c|c|c|c|c|c|}
\hline Gene & $\begin{array}{l}\text { RAPD } \\
\text { Primer }\end{array}$ & $\begin{array}{l}\text { Total } \\
\text { No. of } \\
\text { bands }\end{array}$ & $\begin{array}{l}\text { Total No. of } \\
\text { polymorphic } \\
\text { bands }\end{array}$ & $\begin{array}{l}\text { Polymorphism } \\
\%\end{array}$ & $\begin{array}{l}\text { Primer } \\
\text { efficiency }\end{array}$ & $\begin{array}{l}\text { Primer } \\
\text { discriminatory } \\
\text { power \% }\end{array}$ & $\begin{array}{l}\text { Total No. } \\
\text { of unique } \\
\text { bands }\end{array}$ & $\begin{array}{l}\text { Uniqueness, } \\
\%\end{array}$ & $\begin{array}{l}\text { Total No. of } \\
\text { Monomorphic } \\
\text { bands }\end{array}$ \\
\hline \multirow{4}{*}{$\begin{array}{l}\text { miRNA } \\
\text { patient }\end{array}$} & OPAA11 & 43 & 2 & 4.651162 & 0.013 & 25 & 2.32558 & 1 & 2 \\
\hline & OPU15 & 38 & 2 & 5.263157 & 0.013 & 25 & 2.631578 & 1 & 2 \\
\hline & OPAA17 & 36 & 2 & 5.555555 & 0.013 & 25 & 0 & 0 & 2 \\
\hline & OPD18 & 32 & 2 & 6.25 & 0.013 & 25 & 0 & 0 & 2 \\
\hline Total & & 149 & 8 & 5.369127 & & & 1.342281 & 2 & 8 \\
\hline miRNA & OPAA11 & 24 & 0 & 0 & 0 & 0 & 0 & 0 & 3 \\
\hline \multirow[t]{3}{*}{ Control } & OPU15 & 23 & 0 & 0 & 0 & 0 & 0 & 0 & 3 \\
\hline & OPAA17 & 24 & 0 & 0 & 0 & 0 & 0 & 0 & 3 \\
\hline & OPD18 & 22 & 0 & 0 & 0 & 0 & 0 & 0 & 3 \\
\hline Total & & 93 & 0 & 0 & & & 0 & 0 & 12 \\
\hline \multirow{4}{*}{$\begin{array}{l}\text { ER-a } \\
\text { patient }\end{array}$} & OPAA11 & 81 & 5 & 6.1728 & 0.016 & 27.77 & 2 & 2.46913 & 4 \\
\hline & OPU15 & 79 & 3 & 3.7974 & 0.010 & 16.66 & 0 & 2.53164 & 4 \\
\hline & OPAA17 & 52 & 4 & 7.6923 & 0.013 & 22.22 & 1 & 3.84615 & 4 \\
\hline & OPD18 & 86 & 6 & 6.9767 & 0.020 & 33.33 & 2 & 2.32558 & 4 \\
\hline Total & & 298 & 18 & 6.0402 & & & 5 & 0.67114 & 16 \\
\hline ER-a & OPAA11 & 18 & 8 & 44.4444 & 0.062 & 23.52 & 5.5555 & 1 & 0 \\
\hline \multirow[t]{3}{*}{ Control } & OPU15 & 41 & 10 & 24.3902 & 0.078 & 29.41 & 2.43902 & 1 & 0 \\
\hline & OPAA17 & 25 & 7 & 28 & 0.054 & 20.58 & 8 & 2 & 0 \\
\hline & OPD18 & 44 & 9 & 20.4545 & 0.070 & 26.47 & 6.8181 & 3 & 0 \\
\hline Total & & 128 & 34 & 26.5625 & & & 5.46875 & 7 & 0 \\
\hline
\end{tabular}

Mutation, SNP by ROS

Fluorescence microscopy was performed using specific diagnostic stains (MitoTracker for detection of mitochondrial function defects), DCFHDA for determining ROS expression in tissues and MitSox for discovering the origin of ROS production. Our data showed clear and obvious differences between cancerous and healthy breast tissues. There were clear defects in mitochondrial function represented by defects in the morphology of mitochondria, as mentioned by Dragh et al. (2017). Additionally, ROS staining showed overexpression of ROS in cancerous tissue compared to healthy tissues. MitoSox staining showed excessive production of ROS in affected tissue due to mitochondrial defects, which are considered the origin of ROS production. (figure $6,7,8,9$ ).

\section{Relationship between mutation of breast cancer-related genes and high levels of ROS}

We examined breast tissues by fluorescence microscopy, and our findings showed differences in ROS levels between patient (higher ROS) and control tissues. We suspected an unclear relationship between higher levels of ROS and an increased incidence of SNPs and mutations. Therefore, we performed gene sequencing, which determined the presence of SNPs and different mutations (Table 5). These mutations occurred due to the high level of ROS within breast cancer tissue. Our results are in agreement with those mentioned by (Saha et al.,2009; Martinez - Outschoorn et al.,2012; Gorodetska et al.,2019), who reported that the mutation of BRCA1 (a tumor suppressor gene) in breast cancer can increase cellular ROS, while BRCA1 overexpression reduces ROS levels, so it may contribute to the development of breast cancer. 
Table 5

SNPs and mutations in breast cancer-related genes

\begin{tabular}{|c|c|c|c|c|}
\hline & ABCG2 & ABCB1 & BRCA1 & ER-a \\
\hline \multirow[t]{2}{*}{ SNP } & $239,243,247,267,253,96330$ & $123,118,241$ & 261,224 & $114,244,344,440,586$ \\
\hline & $9649,96412,964282557,2563$ & $3664,3772,3901,4074$ & & 586,594 \\
\hline \multirow[t]{2}{*}{ Mutation } & $\mathrm{C}>\mathrm{T}, \mathrm{C}>\mathrm{T}, \mathrm{C}>\mathrm{T}, \mathrm{T}>\mathrm{C}, \mathrm{T}>\mathrm{C}$ & $\mathrm{T}>\mathrm{C}, \mathrm{C}>\mathrm{T}, \mathrm{C}, \mathrm{T}, \mathrm{A}>\mathrm{G}, \mathrm{A}>\mathrm{G}$ & $\mathrm{T}>\mathrm{C}, \mathrm{T}$ & $\mathrm{C}>\mathrm{T}, \mathrm{C}>\mathrm{G}, \mathrm{C}>\mathrm{G}, \mathrm{T}>\mathrm{C}, \mathrm{C}>\mathrm{G}, \mathrm{T}>\mathrm{G}, \mathrm{C}$ \\
\hline & $T>C, A>C, T>C, A>C, T>G, A>C$ & $\mathrm{G}>\mathrm{T}$ & & \\
\hline \multirow{3}{*}{$\begin{array}{l}\text { Type of } \\
\text { mutation }\end{array}$} & Deletion Insertion, Substitution & Substitution, Substitution, & Insertion, & Substitution, Insertion, \\
\hline & Substitution, Transversion, Substitution & Deletion,'Transition, & deletion & Substitution,Substitution,Insertion \\
\hline & & Transition,Substitution & & \\
\hline \multirow[t]{2}{*}{ a a } & $M>V, A>P, V>M, A>P, Y>S, Y>S$ & $|>|,|>|, S>A, S>T, k>K$ & $\mathrm{~T}>\mathrm{H}$ & $A>A, G>G, C>W, S>Y$ \\
\hline & $M>V, A>P, V>V, V>V, V>V$ & $A>D, G>G$ & & * \\
\hline
\end{tabular}

\section{Discussion:}

One of the most common malignancies in women is breast cancer, with an incidence rate double that of ovarian, stomach, colorectal and cervical cancer and approximately triple that of lung cancer. Many methods have been used to study genetic polymorphisms of genes related to breast cancer, and although the RAPD technique is considered random with reduced reproducibility, we chose it as a rapid and low-price technique (Bidet et al., 2000) and to gain an initial idea of our data to determine the next step of testing. However, we performed a new procedure with some modifications in the traditional RAPD technique when we used the amplified gene as a template in RAPD. This procedure resulted in a higher number of bands yielded with more accuracy and specific data. In the current study, we found that the number of bands per primer for each gene was high. This improved RAPD successfully increased the number of RAPD bands produced from a given PCR product. Therefore, we applied the RAPD technique with 5 specific genes (ABCB1, ABCG2, BRCA1, miRNA-152, ER-a) to generate more bands for detecting genomic alterations in human breast cancer.

The present results showed a reasonable degree of genetic polymorphism detected between normal and breast cancer patients. It showed the high genetic polymorphism in breast cancer patients: The total number of bands in patients were $(214,215,206,298,149)$ band; the overall number were (1082), while the total bands of the control were $(162,114,126,128,93$ ) for ABCG2,ABCB1,BRCA1,ER-a, miRNA -152 genes, respectively; the overall number were (623), this results were higher than the results mentioned by (Ismaeel.,2013) (the total number of bands were 69 when she used total extracted DNA as template and 6 arbitrary primers). Additionally, (Al-ASkeri.,2016) results were lower, with 72 amplified bands in the patient and 28 in the control when he used total extracted DNA as template and five arbitrary primers).

The polymorphic band refers to heterozygous genomic regions. The total number of polymorphic bands in all genes was 85 in the patient and 69 in the control. Monomorphic bands refer to homogenous genomic regions. The total monomorphic bands in all genes in patients were 52 bands, while in controls, there were 40 bands. The total unique bands in all genes were 36 in patient while in control were 24 band. We suggest that the differences in number of bands between patients and control might due to nucleotides sequence of the primers and on the genotype of the breast cancer patients. Notably, the number of compatible sites of primers in breast cancer (ABCB1, ABCG2, BRCA1, miRNA-152, ER-a) genes of breast cancer patients, which are affected by different types of mutations and translocations, will affect the primer-template interaction sites and will result in the loss or profit of bands. As a result, this will lead to differences in the number of amplified bands. The ability of RAPD analysis to detect genetic instability represents the differences between normal and malignant cells that may comprise insertions, deletions and alterations in oncogenes or suppressor genes that could cause cancer (Atienzar et al.,2006).

Differences in the fragment size between patients and controls might refer to the polymorphism also including the differences in molecular weights of amplified bands that resulted from multiple types of mutations and translocation occurring, thus causing mobility shifts of bands and might cause the addition of new band(s) (Misra et al.,1998;ong et al.,1998.;Papadopoulos et al.,2002; Xian et al.,2005;Ibrahim et al.,2010).

Our findings showed differences in primer discriminatory power between patients and controls, whereas the high discriminatory power in patients was $40 \%$ at OPU15; in contrast, the highest primer discriminatory power in controls was $42.85 \%$ at OPAA11. The primer capacity to show polymorphisms in comparison to polymorphisms shown by all primers is called primer discriminatory power (Grundman et al., 1995 ; Ismaeel., 2013). In the current study, the highest primer efficiency in the patient was 0.037 at OPD18, while the highest primer efficiency in the 
control was 0.078 at OPU15. Primer efficiency values range from 0-1 and are defined as the measure of the primer's ability to produce polymorphisms (Newton and Graham, 1997).

ROS are a group of highly reactive oxygen-containing molecules that can induce DNA mutation and physical or chemical changes to DNA in cells, which can affect the interpretation and transmission of genetic information and affect the DNA damage response. (Curtin., 2012; Srinivas et al., 2019). They are molecules capable of freelance and containing at least one oxygen atom and one or more unpaired electrons; this group includes oxygen free radicals. Excessive formation of free radicals contributes to damage at the molecular and cellular levels as well as changes to proteins, carbohydrates and nucleotides (changes in the DNA structure). These changes contribute to the development of many free radical-mediated diseases (Jakubczyk et al., 2020). Interestingly, female steroid estrogens and their several metabolites generate ROS in breast cancer cells. Slow, sustained and moderate levels of ROS produced by estrogens and their metabolites cause the initiation and progression of breast cancer (Johar et al.,2016).

In the current study, the results showed high levels of ROS in the tissues of breast cancer patients compared with controls. This agrees with (Storz., 2005; Liou and storz., 2010), who mentioned that high levels of ROS in cancer cells can result from increased metabolic activity, mitochondrial dysfunction, increased cellular receptor signaling, oncogene activity, etc.

In the current study, The findings showed that patients having tissues with high level of the ROS were also had SNP and mutations in the included genes(Table) which were deletion, insertion, trans version, translation and silent mutation; the presence of SNP in the genes of the BC may be due to high level of the ROS in tissue, whereas ROS might be the cause of mutations; our findings here are in agreement with (Lunec et al., 2002;Noreen et al.,2018) which mentioned the ROS cause the DNA mutations which can induced guanine to thymine transversions or vice versa. Additionally, we agree with Choudhari et al. (2014), who suggested that ROS can be the cause of oxidized purines and pyrimidines. Our results are also in agreement with those of (Szatrowski and Nathan,1991; Retel et al.,1993; Brown and Bicknell, 2001;Noreen et al.,2018), which indicated that mutations caused by ROS mostly affect GC base pair substitutions. Deletions and insertions occur less frequently, while AT base pairs cause rare mutations and single- or double-strand breaks. All these genetic instabilities result in the inactivation of tumor suppressor genes or enhance the expression of proto-oncogenes that strengthen cancer.

\section{Conclusion:}

Our results proved the accuracy of our modification in the traditional RAPD technique, which yielded more specific bands related to genes. Additionally, this test gave us an indication of high polymorphism in patients when compared to controls, which may be related to mutations or modifications. There were significant differences between patients and healthy women in regard to the expression of breast cancer-related genes on the levels of ROS production, SNPs and mutation occurrence. High levels of estrogens may be the direct effector in the induction and promotion of breast cancer, and this hormone can be inserted into the body by different routes, such as contraceptive pills, cosmetics and xenoestrogens present in the environment. Although our study did not include genes concerned with family history incidence of breast cancer, we suggested from our data that most breast cancers in Iraqi women are not family related but rather drug resistance and estrogen response. We can predict and diagnose breast cancer early upon analysis of our chosen genes, and our study allows us to employ these genes in the early prediction of breast cancer.

\section{Declarations:}

\section{Ethical approval:}

informed consent: all patients and healthy women participated in the study were signed an informed consents prior the study (samples attached at the end of this file).

\section{Consent of publication:}

Authors declare their consent of publication

\section{Availability of supporting data:}

Not applicable

\section{Competing interests:}

Authors show no competing interests

\section{Funding:}


No funding was available

\section{Authors contributions:}

MAD designed the study and performed the statistical analysis. ZZG carried out the molecular genetic work. MAD participated in the sequence alignment and drafted the manuscript. ZZG write the manuscript. All authors read and approved the final manuscript

\section{ACKNOWLEDGEMENT}

Much obligation was given to the Maysan Health Directorate/AL-Sader Teaching Hospital/AL-Shifa Tumor Treatment Center and all the staff of the AL-Shifa Tumor Treatment Center to facilitate the approval of the collection of blood samples from breast cancer patients. My thanks and appreciation to all breast cancer women patients and normal people for their consent to draw blood samples from them.

\section{References:}

1. Abd Ellatif, M., Zahran, M. A., Denaiwar, A., Elbaz, A., \& Abdel Azeez, H. A. (2016). Study of polymorphism of the estrogen receptor alpha gene as a genetic marker for the risk of breast cancer.

2. Al-Amri, R. J., Alotibi, M. K. H., Al-Raddadi, R. I., Shebli, W. T. Y., Fallatah, E. I. Y., Alhujaily, A. S., \& Mohamed, H. S. (2020). Estrogen Receptor 1 Gene (ESR1) rs2234693 Polymorphism and Breast Cancer Risk in Saudi Women. Asian Pacific Journal of Cancer Prevention, 21(11), 3235-3240.

3. Al-Askeri, M. A. (2016). Genetic Polymorphism in Iraqi Females Diagnosed with Breast Cancer Using Random Amplification of Polymorphic DNA Technique.

4. Atienzar, F. A., \& Jha, A. N. (2006). The random amplified polymorphic DNA (RAPD) assay and related techniques applied to genotoxicity and carcinogenesis studies: a critical review. Mutation Research/Reviews in Mutation Research, 613(2-3), 76-102.

5. Bidet, P., Lalande, V., Salauze, B., Burghoffer, B., Avesani, V., Delmée, M.... \& Petit, J. C. (2000). Comparison of PCR-ribotyping, arbitrarily primed PCR, and pulsed-field gel electrophoresis for typing Clostridium difficile. Journal of clinical microbiology, 38(7), 2484.

6. Brown, N. S., \& Bicknell, R. (2001). Hypoxia and oxidative stress in breast cancer Oxidative stress-its effects on the growth, metastatic potential and response to therapy of breast cancer. Breast cancer research, 3(5), 1-5.

7. Chauhan P, Yadav R, Kaushal V, Kadian L (2019). Evaluation of genetic polymorphism in estrogen receptor a gene as breast cancer risk. Biomed Res, 30, 72-7.

8. Chen, L., Manautou, J. E., Rasmussen, T. P., \& Zhong, X. B. (2019). Development of precision medicine approaches based on interindividual variability of BCRP/ABCG2. Acta Pharmaceutica Sinica B, 9(4), 659-674.

9. Choudhari, S, K.,Chaudhary, M.,Gadbail,A.R.,Sharma,A.,\&Tekade,S.(2014).Oxidative and antioxidative mechanisms in oral cancer and precancer: a review.oral oncology, 50(1),10-18.

10. Curtin, N. J. (2012). DNA repair dysregulation from cancer driver to therapeutic target. Nature Reviews Cancer, 12(12), 801-817.

11. Gholipoorfeshkecheh, R., \& Arjunan, S. (2014). Genotyping frequent BRCA1 SNPs in familiar breast cancer in Indian population by restriction fragment length polymorphism and sequencing. Adv App/ Sci Res, 5, 262-267.

12. Gorodetska, I., Kozeretska, I., \& Dubrovska, A. (2019). BRCA genes: the role in genome stability, cancer stemness and therapy resistance. Journal of Cancer, 10(9), 2109.

13. Grundman, H., Scheider, C.,Hartung, D., Daschner, F.D., and Pitt, T.L. 1995. Discriminatory power of three based typing techniques or P. aeruginosa. J.Clin. Microbiol. 33(3): 528-534.

14. Haider, A. J., Briggs, D., Self, T. J., Chilvers, H. L., Holliday, N. D., \& Kerr, I. D. (2011). Dimerization of ABCG2 analysed by bimolecular fluorescence complementation. PLoS One, 6(10), e25818.

15. Ibrahim, M. A., Saleh, N., Archoukieh, E., Al-Obaide, H., Al-Obaidi, M., \& Said, H. (2010). Detection of novel genomic polymorphism in acute lymphoblastic leukemia by random amplified polymorphic DNA analysis. Int $J$ can Res, 6, 19-26.

16. IÇDUYGU, F. M., ŞAMLI, H., EVRENSEL, T., ÖZGÖZ, A., ÖZTÜRK, K. H., CANHOROZ, M.... \& IMIRZALIOĞLU, N. Association between MDR 1 (ABCB1) gene C3435T, C1236T, G2677T/A, A2956G polymorphisms and the risk of breast cancer among Turkish Women. SDÜ Tıp Fakültesi Dergisi, 27(3), 345-352.

17. Ismaeel, H. M. (2013). Identification of genomic markers by RAPD-PCR Primers in Iraq Breast Cancer patients. Iraq J Sci, $54,97-104$.

18. Jakubczyk, K., Dec, K., Kałduńska, J., Kawczuga, D., Kochman, J., \& Janda, K. (2020). Reactive oxygen species-sources, functions, oxidative damage. Polski merkuriusz lekarski: organ Polskiego Towarzystwa Lekarskiego, 48(284), 124-127.

19. Jin, Y. (2020). Blood DNA methylation as a surrogate epigenetic biomarker in study of night shift work and breast cancer. 
20. Johar, R., Sharma, R., Kaur, A., \& K Mukherjee, T. (2016). Role of reactive oxygen species in estrogen dependant breast cancer complication. Anti-Cancer Agents in Medicinal Chemistry (Formerly Current Medicinal Chemistry-Anti-Cancer Agents), 16(2), 190-199.

21. Liou, G. Y., \& Storz, P. (2010). Reactive oxygen species in cancer. Free radical research, 44(5), 479-496.

22. Lunec, J., Holloway, K. A., Cooke, M. S., Faux, S., Griffiths, H. R., \& Evans, M. D. (2002). Urinary 8-oxo-2'-deoxyguanosine: redox regulation of DNA repair in vivo?. Free Radical Biology and Medicine, 33(7), 875-885.

23. Martinez-Outschoorn, U. E., Balliet, R., Lin, Z., Whitaker-Menezes, D., Birbe, R. C., Bombonati, A.... \& Lisanti, M. P. (2012). BRCA1 mutations drive oxidative stress and glycolysis in the tumor microenvironment: implications for breast cancer prevention with antioxidant therapies. Cell Cycle, 11(23), 4402-4413.

24. Meshram, Y. (2019). BRCA1 and BRCA2: Role in breast cancer. International Journal of Scientific Research and Reviews.

25. Misra, A., Sulaiman, I. M., Sinha, S., Sarkar, C., Mahapatra, A. K., \& Hasnain, S. E. (1998). Genetic alterations in brain tumors identified by RAPD analysis. Gene, 206(1), 45-48.

26. Newton, C.R. and Graham, A. 1997. Polymerase Chain Reaction. Bios Scientific publishers. Oxford, UK.

27. Nguyen-Dien, G. T., Smith, R. A., Haupt, L. M., Griffiths, L. R., \& Nguyen, H. T. (2014). Genetic polymorphisms in miRNAs targeting the estrogen receptor and their effect on breast cancer risk. Meta gene, 2, 226-236.

28. Ni, Z., Mark, M. E., Cai, X., \& Mao, Q. (2010). Fluorescence resonance energy transfer (FRET) analysis demonstrates dimer/oligomer formation of the human breast cancer resistance protein (BCRP/ABCG2) in intact cells. International journal of biochemistry and molecular biology, 1(1), 1.

29. Noreen, A., Bukhari, D. A., \& Rehman, A. (2018). Reactive oxygen species: Synthesis and their relationship with cancer-a review. Pakistan Journal of Zoology, 50(5).

30. Ong, T. M., Song, B., Qian, H. W., Wu, Z. L., \& Whong, W. Z. (1998). Detection of genomic instability in lung cancer tissues by random amplified polymorphic DNA analysis. Carcinogenesis, 19(1), 233-235.

31. Papadopoulos, S., Benter, T., Anastassiou, G., Pape, M., Gerhard, S., Bornfeld, N.... \& Dörken, B. (2002). Assessment of genomic instability in breast cancer and uveal melanoma by random amplified polymorphic DNA analysis. International journal of cancer, 99(2), $193-200$.

32. Ponglikitmongkol M, Green S, Chambon P (1988). Genomic organization of the human oestrogen receptor gene. EMBO J, 7, $3385-8$

33. Retèl, J., Hoebee, B., Braun, J. E., Lutgerink, J. T., van den Akker, E., Wanamarta, A. H.... \& Lafleur, M. V. M. (1993). Mutational specificity of oxidative DNA damage. Mutation Research/Genetic Toxicology, 299(3-4), 165-182.

34. Saha, T., Rih, J. K., \& Rosen, E. M. (2009). BRCA1 downregulates cellular levels of reactive oxygen species. FEBS letters, 583(9), 1535-1543.

35. Sambrook, J., \& Russell, D. (2001).Molecular cloning: A laboratory manual., 3 rd edn. (Cold Spring Harbor Laboratory press:Cold Spring Harbor, NY,USA).

36. Sato, H., Nogueira-de-Souza, N. C., D'Amora, P., Silva, I. D., Girão, M. J., \& Schor, E. (2008). Intron 1 and exon 1 alpha estrogen receptor gene polymorphisms in women with endometriosis. Fertility and sterility, 90(6), 2086-2090.

37. Seufi, A. M., Ibrahim, S. S., Elmaghraby, T. K., \& Hafez, E. E. (2009). Preventive effect of the flavonoid, quercetin, on hepatic cancer in rats via oxidant/antioxidant activity: molecular and histological evidence. Journal of Experimental \& Clinical Cancer Research, $28(1), 1-8$.

38. Sheng, X., Zhang, L., Tong, N., Luo, D., Wang, M., Xu, M., \& Zhang, Z. (2012). MDR1 C3435T polymorphism and cancer risk: a meta-analysis based on 39 case-control studies. Molecular biology reports, 39(7), 7237-7249.

39. Srinivas, U. S., Tan, B. W., Vellayappan, B. A., \& Jeyasekharan, A. D. (2019). ROS and the DNA damage response in cancer. Redox biology, 25, 101084.

40. Storz, P. (2005). Reactive oxygen species in tumor progression. Front Biosci, 10(1-3), 1881-1896.

41. Sun, Y. S., Zhao, Z., Yang, Z. N., Xu, F., Lu, H. J., Zhu, Z. Y... \& Zhu, H. P. (2017). Risk factors and preventions of breast cancer. International journal of biological sciences, 13(11), 1387.

42. Surzycki, S. (2012). Basic techniques in molecular biology. Springer Science \& Business Media.

43. Szatrowski, T. P., \& Nathan, C. F. (1991). Production of large amounts of hydrogen peroxide by human tumor cells. Cancer research, 51(3), 794-798.

44. Tazzite, A., Kassogue, Y., Diakité, B., Jouhadi, H., Dehbi, H., Benider, A., \& Nadifi, S. (2016). Association between ABCB1 C3435T polymorphism and breast cancer risk: a Moroccan case-control study and meta-analysis. BMC genetics, 17(1), 1-11.

45. Wu, H., Liu, Y., Kang, H., Xiao, Q., Yao, W., Zhao, H.... \& Wei, M. (2015). Genetic variations in ABCG2 gene predict breast carcinoma susceptibility and clinical outcomes after treatment with anthracycline-based chemotherapy. BioMed research international, 2015.

46. Xian, Z. H., Cong, W. M., Zhang, S. H., \& Wu, M. C. (2005). Genetic alterations of hepatocellular carcinoma by random amplified polymorphic DNA analysis and cloning sequencing of tumor differential DNA fragment. World Journal of Gastroenterology: WJG, 11(26), 4102. 


\section{Figures}

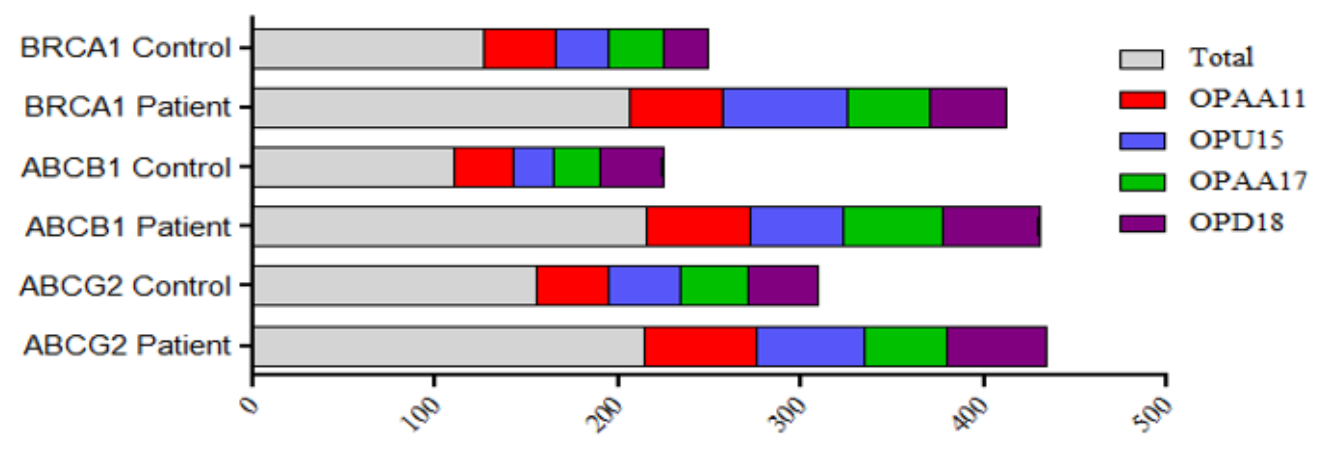

Total Number of bands per locus in BC Genes

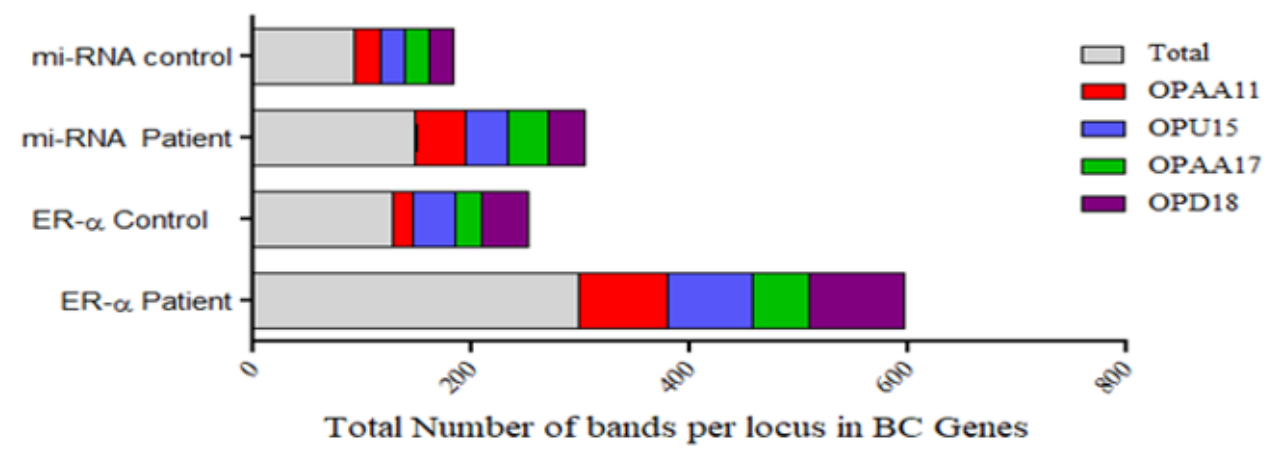

Figure 1

total number of bands per locus in BC genes
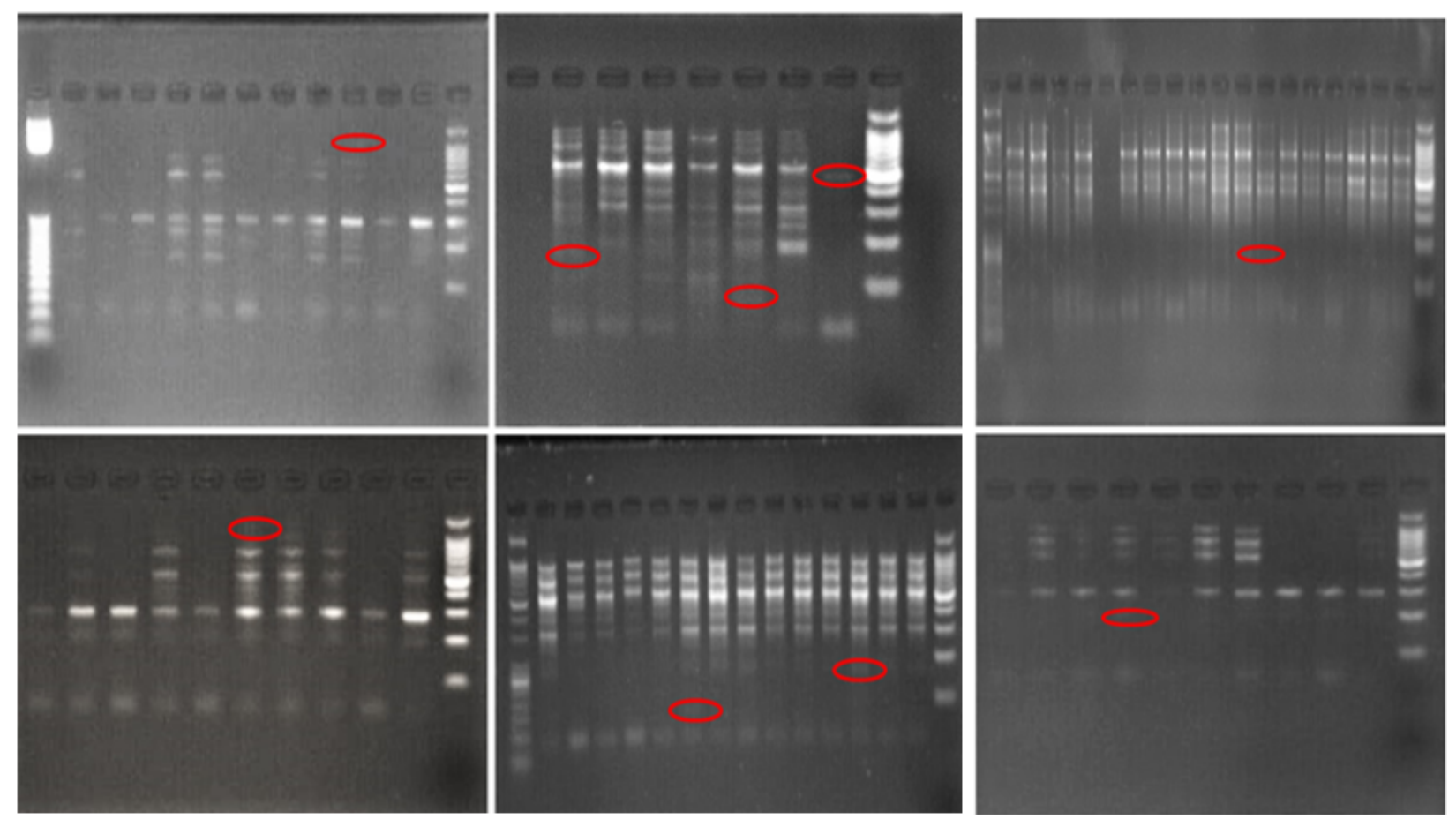

Figure 2 
PCR assay for BC-related genes with RAPD polymorphisms. Agarose gel of $2 \%$ loaded with DNA ladder of (25-1100 bp) and four RAPD primers (OPAA11, OPU 15, OPAA17 and OPD 18). Red circles refers to unique bands.
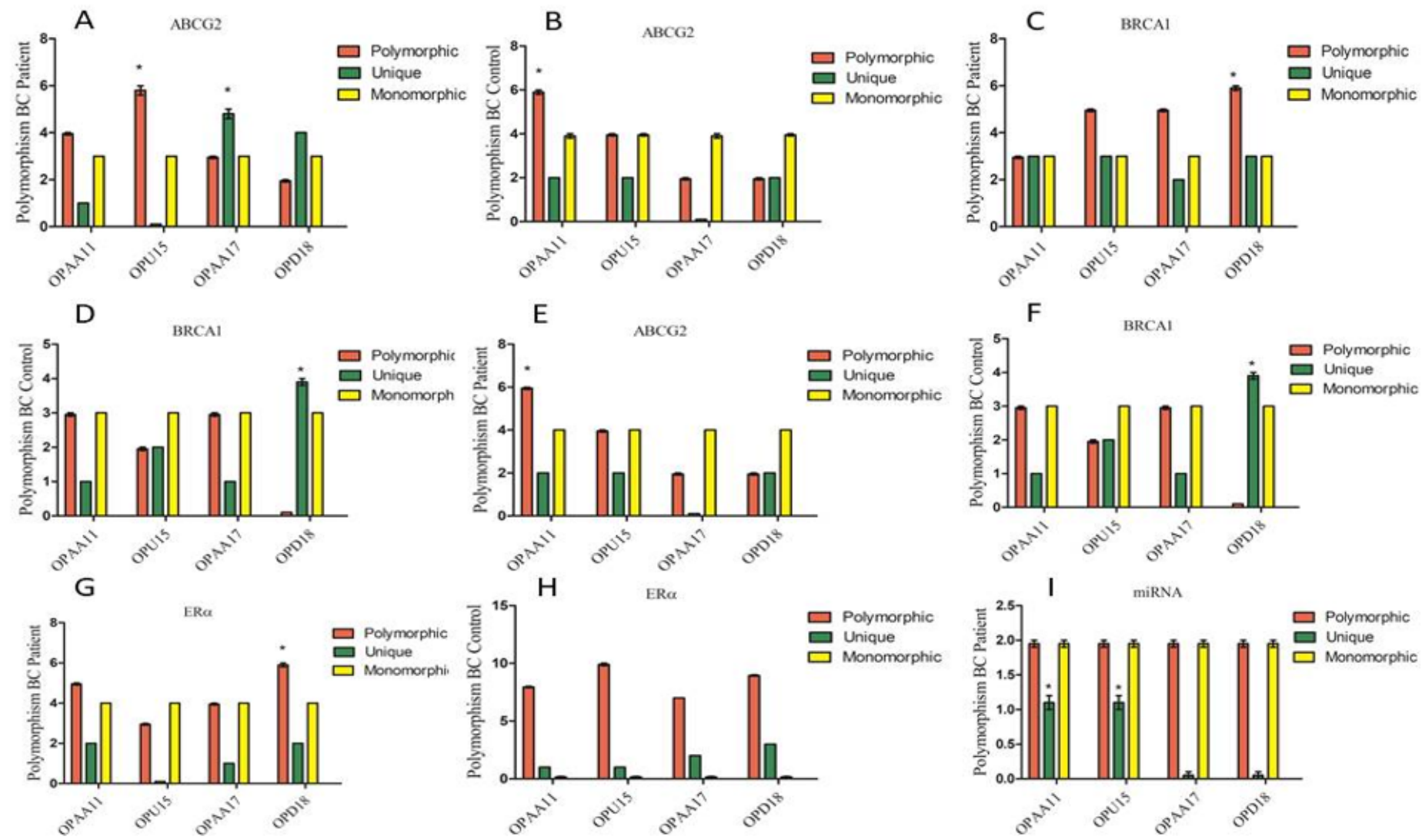

Figure 3

Ability of RAPD primers to generate polymorphic, monomorphic and unique bands 
A
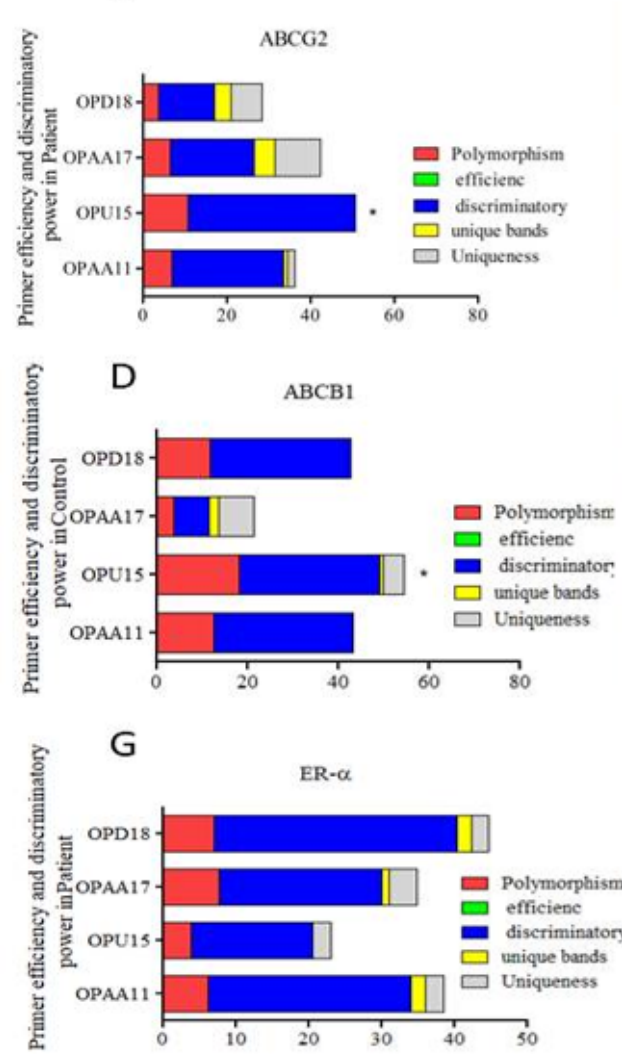

B
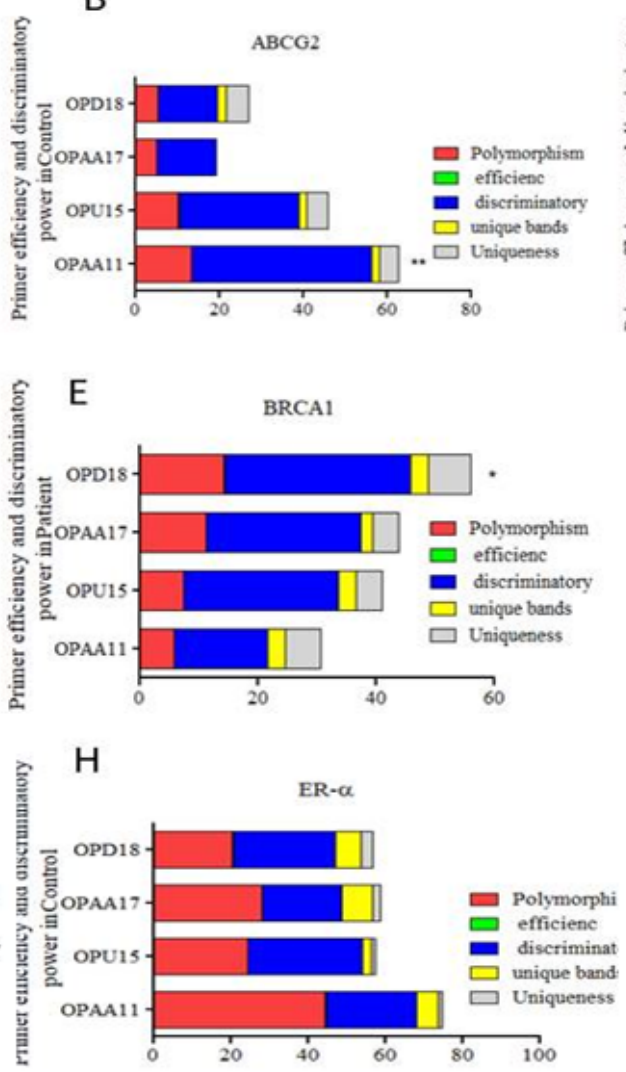

C
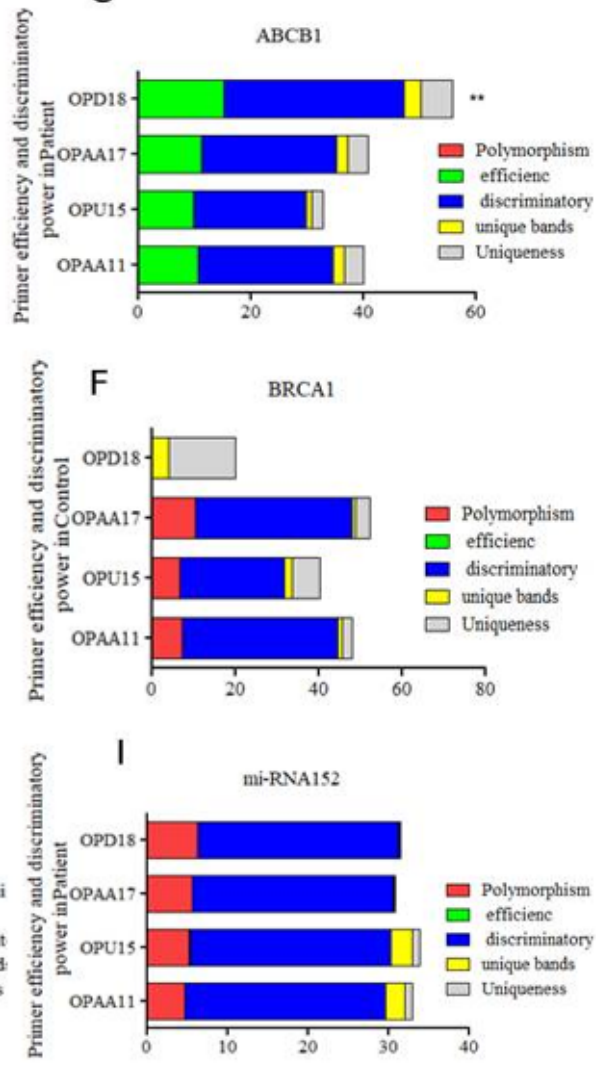

Figure 4

RAPD primer efficiency and discrimination power in breast cancer-related genes. 

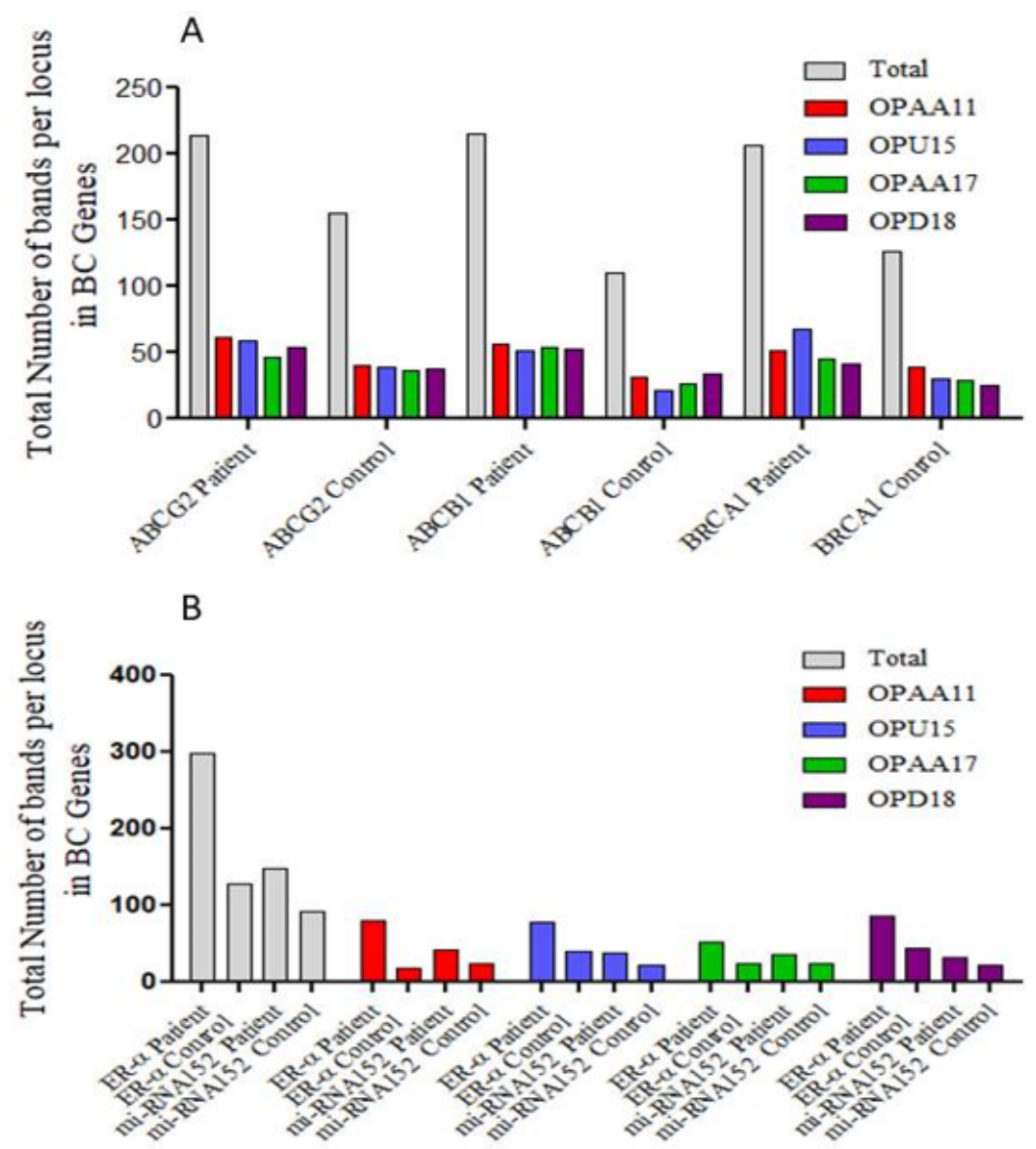

Figure 5

Genes with a total number of pear locus bands in the patients and controls.
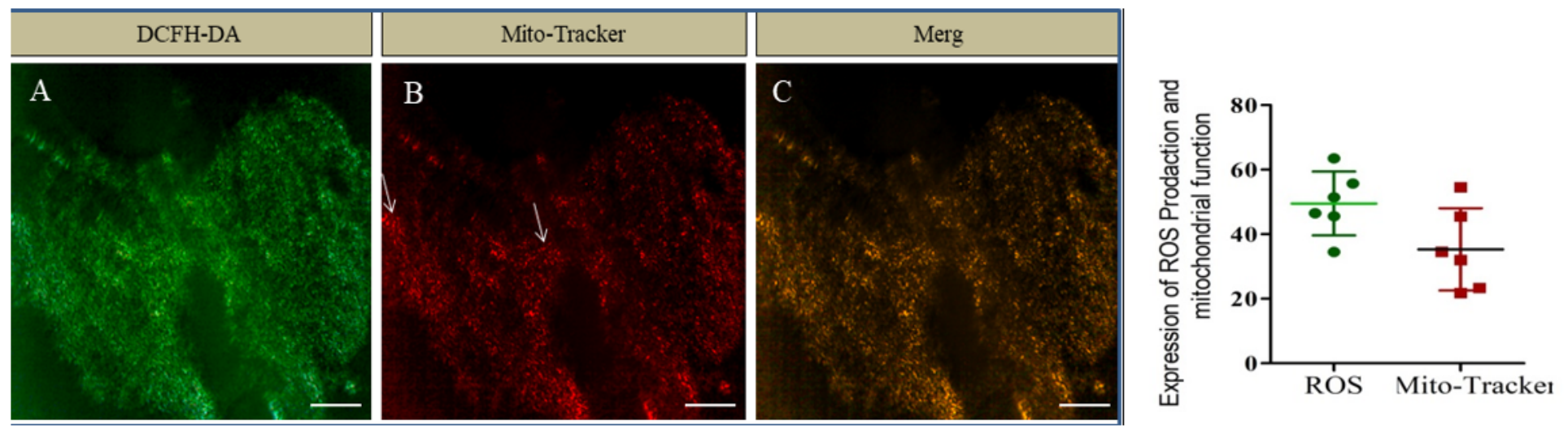

Figure 6

ROS production in cancerous tissue and clear defects in mitochondrial function. 

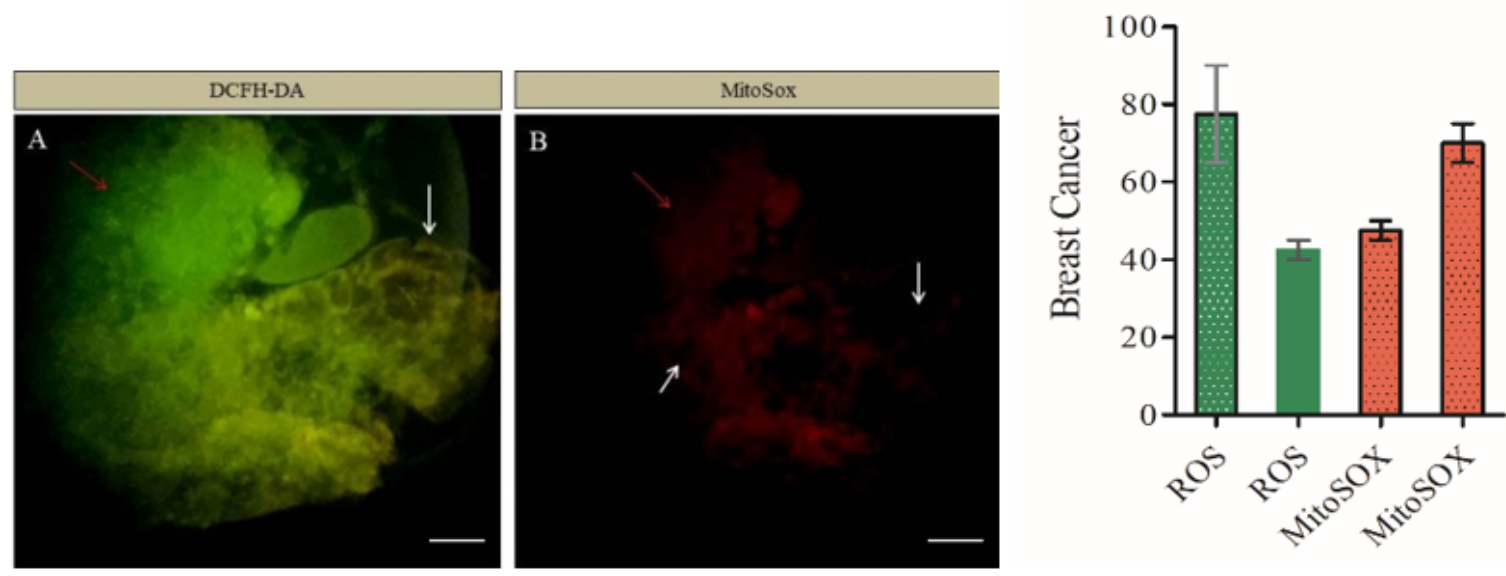

\section{Figure 7}

ROS originated from mitochondrial defect.
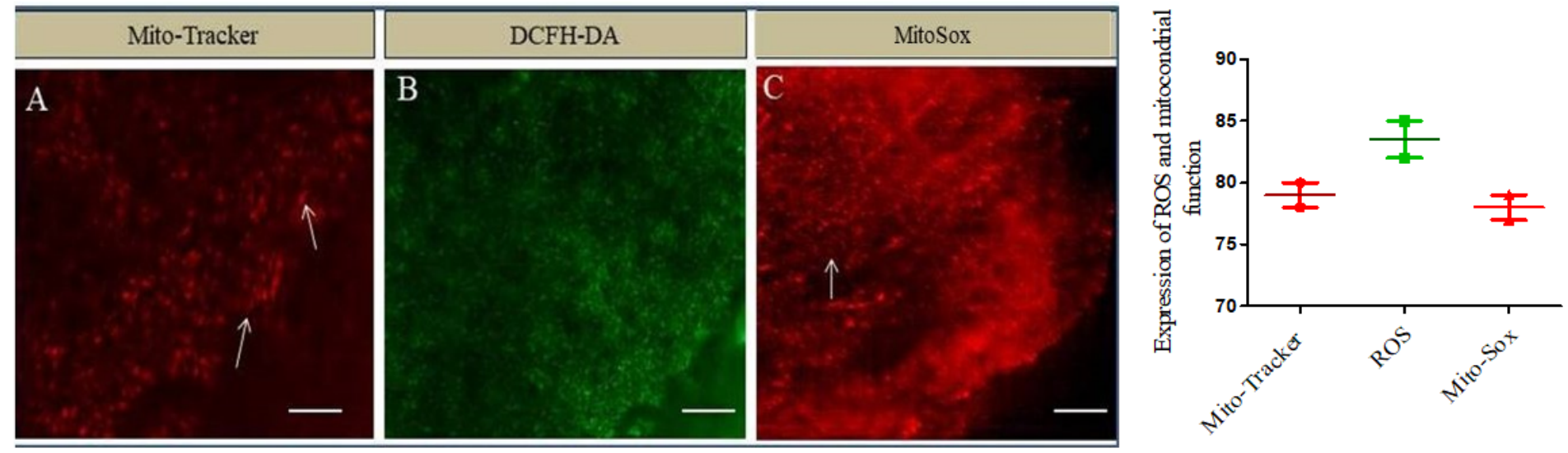

Figure 8

Fluorescence microscopy of breast cancer tissue: A; MitoTracker staining to detect mitochondrial function defects; B; DCFH-DA specialized staining to detect ROS expression, C; MitoSox staining to detect the origin of ROS
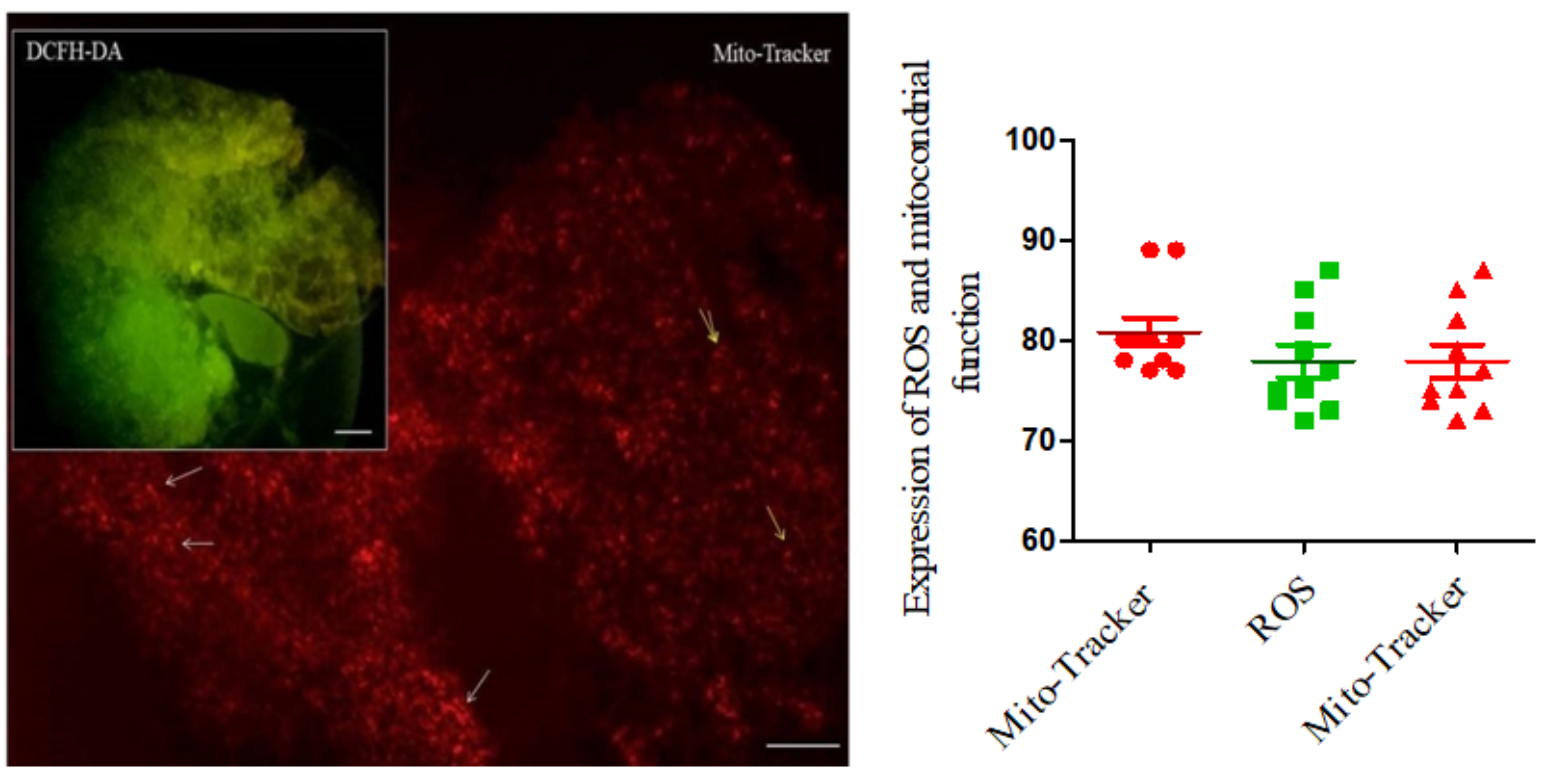

Figure 9 
Fluorescence microscopy of breast cancer tissue: arrows show (yellow) normal and (white) affected tissues.
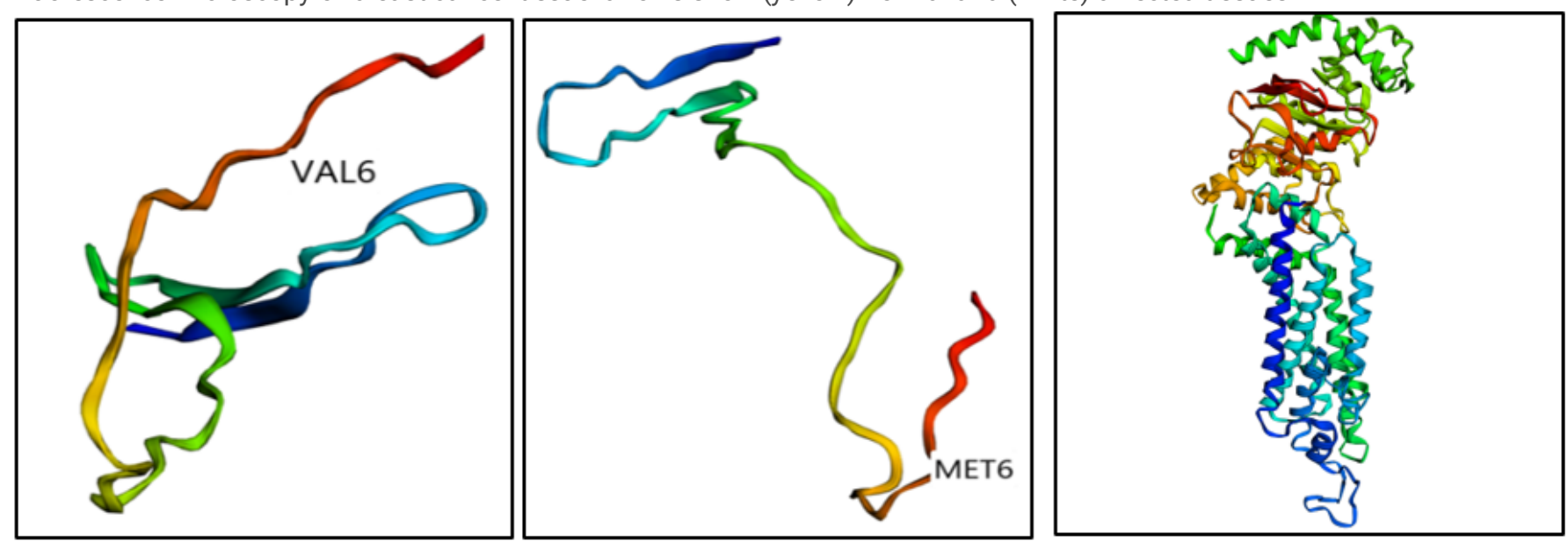

Figure 10

3D shape: $(A, B, C) 3 D$ the protein peptide chain. (D) 